\title{
Restoring autonomy. Symmetry and asymmetry in care relationships
}

\begin{abstract}
In this article the complexity of a professional care relationship as a whole of symmetrical and asymmetrical, formal and informal dimensions, is presented. Its ethical simplicity, however, is safeguarded as long as the telos of a care relationship is seen as the restoration of the autonomy of the care receiver. Autonomy is interpreted as the capability of persons to develop their uniqueness throughout their life course. The undeniable asymmetry of the care relationship is an essential, but temporary moment in its dynamics. The dynamics of a care relationship corresponds to the heart of the Christian ethos: in the Christian narrative, the asymmetry of humiliation precedes the exaltation, understood as the restoration of human dignity as 'living upright'. The theological concept of exaltation can be interpreted as God's 'care for autonomy' in a ethics of care.
\end{abstract}

\section{INTRODUCTION}

The 'work on others', as François Dubet calls a professional care relationship ${ }^{2}$, has become a confusing world. Global society develops in large parts of the world from a system of vertical, hierarchical communities toward networks of egalitarian relationships, where citizens according to democratic ideals are treated as equals. One does no longer become a good, healthy citizen by submitting oneself to a disciplinary regime and en insert oneself into a pre-existing, dominant discourse, but by elaborating a reflexive identity within a fast changing dialogical context. The process of socialization no longer takes place by outward collective discipline, but by stimulating an internal locus of control.

The institutional role played by care- and welfare institutions (churches included) has changed in like manner: from aristocratic charity organizations, taking pity on the poor, sick and helpless, they turned into societal enterprises, somewhere in between the private and public sphere. For them, mercy is a matter of offering services to clients. As a care worker, in representing your organization, you are a citizen in contact with a fellow citizen with a 'help-question'.

The care relationship is one among equals. But what kind of equality is implied? Does equality here only stands for a political fiction? Isn't care per definition a relationship of power and dependency, an exclusively asymmetrical relationship of a healthy relatively well-to-do person bending over often literally a victim of bad fate? Any effort to redefine the relationship of

1 The author is Professor of Ethics at the Protestant Theological University, Kampen, the Netherlands, and Extraordinary Professor of Systematic Theology and Ecclesiology, University of Stellenbosch.

2 François Dubet, Le declin de l'institution, Paris 2002. I am defining care workers here as broad as possible as everyone who is more or less professionally involved in 'working-on-others', including health care, education, welfare, spiritual care, pastoral care and/or ministry. 
care in terms of a service offered to autonomous clients collides with our fundamental intuition of how a care relationship starts: with the spontaneous benevolent action of one person, a one sided act of mercy.

'Workers-on-others' simultaneously move in and between different relational worlds, both symmetric and asymmetric. A professional web of relationships, however, is even more complex. It also has personal and impersonal dimensions, both formally and informally. A care relationship is personal, because it cannot start and be upheld without compassion and friendship. A care relationship without this informal person-to-person dimension would turn it into a facility machinery. But professional care has also formal dimensions, precisely because it is professional. There is authority implied in professional expertise, an acquired set of specialized knowledge and distinguished skills.

So professional care givers move simultaneously in and between the world of (1) their métier (2) their inner, personal world, and (3) the world of their organization and its political and social context. Three worlds which they have to keep together in their professional identity. The more or less coherent integrity they are able to obtain, in holding these worlds together, might be called their 'professionalism.' A heavy task, because conflicts and frictions between these three worlds regularly occur. In the course of a professional career, every worker develops his or her own personal style, in order to obtain an optimal integrity. One might even say: one's style is one's professionalism.

The care relationship is a complex interplay of different relationships, both formal and informal, and symmetric and asymmetric. I therefore speak of a pragmatics of care, as a practice including different kinds of agency.

\section{THE ETHICAL DIMENSIONS IN THE RELATIONSHIP OF CARE}

I would now like to explore the ethical dimensions of this complex - and often conflict ridden - interlocking of kinds of relationships within the encompassing care relationship a bit further.

First, there is the distinction between symmetrical and asymmetrical aspect of the relationship. Asymmetrical are those relationships where one outweighs the other. Because he or she owns more knowledge or discernment (the doctor and the patient, the mechanic and the driver, the teacher and the student), more experience (the older and the younger), more power (the king and his subjects), more vigour and mobility (the healthy compared to the ill patient). We may call these vertical relationships. Symmetrical are those relationships where both partners are equals in relation to the goal of their relationship. They are equal in function (colleagues), in love (partners), in dignity (human beings)), in rights and obligations (citizens), in opportunity of beating the other (sports). I call them here horizontal relationships.

One person bending oneself over to someone in mercy and compassion, without having to expect a quid pro quo in return. This still defines the informal, asymmetrical heart of care. There is no equality. The one is agens, the other patiens. The one is moved by mercy and is spontaneously assisting the other in his or her need. The Good Samaritan still represents the icon story of the care sector, how bureaucratized and rationalized it may seem. Without a care giver moved with inner compassion ('into his intestines', as Luke says literary in Greek) by another's fate, no 'care sector' will survive. However, I will show further on that the Samaritan story is only read half, if its initial asymmetry is not interpreted within its dramatic framework, aiming at the restoration of the victim's autonomy. Moreover, the informal asymmetry only represents one aspect of the professional care relationship. Professionals, managers, and clients also have a formal relationship with each other within an institutional setting. Institutions regulate and control impersonal relationships, in which people meet and work together anonymously. 
Paul Ricoeur once distinguished between relationships to the neighbour and relationships with the other as socius. ${ }^{3}$ Meeting a neighbour is a momentaneous event, without structure or history. No third persons are involved. Characteristic for socius relationships is, however, that they are mediated. They don't occur in the intimacy of a personal encounter but within societal frameworks. I meet the socius in his or her 'capacity as ....' (patient, physician, nurse, or: client and fellow-citizen). The neighbour is the one who I encounter unmediated, personally, 'face to face'. Characteristic for a modern professional of care is the conflict ridden combination of neighbour and socius dimensions within the one relationship of care. There is no good care without intimacy. At the same time institutional care is heavily directed towards evidence based control and efficiency. While care for one neighbour per definition without limits, care for a socius is limited by the care for a second (and third, fourth....) neighbour.

The care relationship has another formal, though asymmetrical aspect, defined by the craftsmanship of the care giver, and the dependency on it of the care receiver. His highly skilled medical expertise for example, gives the doctor a power position in the relationship. But this also applies for the hermeneutical and rhetorical skills of a pastor. He is a professional listener and interpreter, hearing what someone really said in ( and sometimes despite) what he said.

Finally, there is also a informal, asymmetrical dimension in care relationships, visible especially in settings of welfare work or pastoral care. During a care trajectory a kind of intimacy can arise, that has the characteristic of a friendship relationship. Within the so called Dutch 'presentiebenadering' ('presence approach', Andries Baart), it is even claimed that any relationship of care cannot succeed if it is not based on the sustainable trust of a 'buddy' relationship with the client. ${ }^{4}$

The professional care relationship is a complex mixture of asymmetrical and symmetrical, formal and informal relations. My thesis - which I elaborated elsewhere ${ }^{5}$ - is that every dimension in the care relationship has its specific moral register, framed in a specific type of discourse. Professionalism presupposes a simultaneous mastery of several moral languages.

\section{AUTONOMY AS THE TELOS OF CARE RELATIONSHIPS}

Does the complexity of the care relationships in the end only leads to a Babylonian confusion of tongues? It is my contention that it will not, as long as the inner telos of the care relationship is kept in view: the autonomy of the care-receiver. But let's be clear in our understanding of autonomy. With Paul Ricoeur I choose not to link the ideal of autonomy historically to European modernity, but anthropologically to the vulnerable vitality of the human condition as such. Autonomy is a quasi-universal shared value for humans, where and whenever they live. So I understand autonomy not as the independent freedom of a rational individual, but as the capability of persons to develop their uniqueness during their life course. Autonomy is the capability to flourish as a human.

What makes us human? The capability to be able, to perform something in the world, Ricoeur says. The power to speak, the power of agency, the power to persist in time, the power to be nobody else but me. According to Ricoeur the ontological characteristic par excellence of human beings is that they are hommes capables, capable humans. ${ }^{6}$ As such they affirm life, and desire to live as vital as possible. With Spinoza one can say that every human being aims to persevere,

3 Paul Ricoeur, « Le Socius et le prochain ». In: idem, Histoire et Vérité. Paris 1955, 99-112.

4 Andries Baart, Een theorie van de presentie. Utrecht 2004. Idem, "Als een vriend... En wat dat mogelijk betekent”, in: Tijdschrift voor Humanistiek, 5 (2004), no. 20, 44-62.

5 Cf. my In andermans handen. Over flow en grenzen in de zorg. Zoetermeer 2011.

6 Paul Ricoeur, Parcours de la reconnaissance, Paris 2004, 149-177. 
arduously desires to continue to be. In this persistent longing for being able (conatus) humans are vulnerable and dependent on others from their beginnings. Their birth already is precarious, and also do they not have their dying to theirs disposal. Often they lack the power to speak, to act, to build up a personal identity, to estimate and respect themselves, to live on their own account. Either because these powers are denied by others, or by fate. For all these powers they have to rely on others.

Therefore, people suffer, as they are assaulted in their capabilities, their vital impetus to endure. They would want to be and do something that they cannot be or do anymore. Suffering includes more than the experience pain. Only people who have the capacity of being able, can suffer, can be hurt. ${ }^{7}$ Those who suffer, are thrown back to themselves, whereas they would want to turn their attention to the world. They feel separated of others who do not understand them, who are not able to understand them nor help them, though they ache for community. They are no longer able to express in words and phrases what they feel, but can only resort to crying of screaming. They are condemned to passivity, in their bed or living room, or in a prison cell. Their life narrative is broken, they have lost its authorship. Eventually sufferers may lose their self esteem, and consider their life as sense- and worthless. Their ontological status as homme capable is reduced to zero. They are despising themselves. The destructivity of suffering shows how fundamental the 'capability of being able' is for human beings: suffering is the expression of human dignity, being violated.

In a similar manner, Karl Barth elaborates in Church Dogmatics III, 4 on 'the will to live' as a divine command. 'Life demands, indeed God creates for it, respect even in its form of impulsive life'. ${ }^{8}$ The 'will to be healthy' is an intrinsic part of this will to live. Barth defines health as the strength for human life. 'Health means capability, vigour and freedom. It is strength for human life. (...) If man may and should will to live then obviously he may and should also will to be healthy and therefore to be in the possession of this strength too.' Health is not a goal in itself, but allows people the capability ('Fähigkeit') to exercise the psychical and physical functions, required to be human.' Health is the strength to be as man. It serves human existence in the form of capacity, vitality and freedom to exercise the psychical and physical functions, just as these themselves are only functions of human existence.' ${ }^{9}$ Who falls ill, is not necessary unhealthy, in the sense that the strength to be human lacks him or her. There has been an assault on the functions that support him or her in this capability, but the strength of being human may remain unbroken. An essential element in both health and spiritual care is to appeal to the patient's own 'will to be healthy'. ${ }^{10}$ To someone who has to live permanently with limitations and handicaps, the will to live healthy means exploring ánd exploiting the strength to live fully with his or her limitations.

Autonomy as an ideal in a ethics of care should be connected to this primordial human strength, the will to live healthy, the exercise in daily praxis of the fundamental affirmation of life. Autonomy functions as the ethical horizon in care relationships: people are enabled, within the confinements of their context and situation, to develop their capability to be able to ...., and be the person they choose to be, given their limitations. The economist and Nobel prize winner Amartya Sen - whose work Paul Ricoeur feels quite congenial to ${ }^{11}$ - speaks of capabilities, understood as the ability (the free opportunity) to have capacities ('achieved

7 Paul Ricoeur, «La souffrance n’ est pas la douleur ». Psychiatrie française, juni 1992. [http://www.

fondsricoeur.fr/photo/la\%20 souffrance $\% 20$ n $\% 20$ est $\% 20$ pas $\% 201 \mathrm{a} \% 20$ douleur.pdf]

8 Karl Barth, Church Dogmatics, III, 4. The Doctrine of Creation, New York 1961, 346.

9 Idem 356v.

10 Idem, 358. Cf. H.- M. Rieger, "Gesundheit als Kraft zum Menschsein. Karl Barths Ausführungen zur

Gesundheit als Anstoß für gesundheitstheoretische und medizinethische Überlegungen”, in: Zeitschrift für Evangelische Ethik, 52 (2008), 183-199.

11 Paul Ricoeur, Parcours de la Reconnaissance, Paris 2004, 225vv. 
functionings'). 'A person's "capability" refers to the alternative combinations of functionings that are feasible for her to achieve. Capability is thus a kind of freedom: the substantive freedom to achieve alternative function combinations (or, less formally put, the freedom to achieve various lifestyles.' ${ }^{12}$ The main value in the ethics of care should not be the promotion of well being of happiness of care receivers, or meeting their preferences or wants, but more fundamentally, the optimal restoration of their capability to lead the sort of life that, and be the person who they have reasons to value. ${ }^{13}$

Even in those cases, when this autonomy is highly fictional and its horizon far away (for example in the care of severely mentally retarded or people suffering from dementia) autonomy as the capability of persons to develop their uniqueness ${ }^{14}$ still functions as a beneficial fiction or does it belong to the category of hope? - that guarantees the equality of care givers and care receivers and brings them into a permanent dialogue of care.

In Talk to her (Hable con ella, 2002) a movie made by the Spanish director Pedro Almodóvar, the lives of the male nurse Benigno and journalist/writer Marco cross when both take care of their partners in a hospital; two women, in a persistent coma after an accident. They get befriended. Whereas Marco in the hours preceding Lydia's accident (as a matador, she was crush by the horns of a bull) talked ceaselessly to her, he now sits silent at her bed, not being able to express a word to her. Benigno at the contrary, talks and talks to Alicia, a dancer in whom he, just before she was hit by a car while crossing the street, got obsessively interested and who he is now allowed to take care of as a nurse. 'Talk to her', Benigno says to Marco. 'Why should I? She can't hear me, her brains are dead and her coma is irreversible', he answers. 'Because you never know', Benigno replies, 'a miracle might happen'. Benigno communicates with Alicia quite naturally and normally - or should I say: humanly - by taking her within his 'fictional' horizon of autonomy. Whereas Marco, footing firmly in medical reality, is unable to approach Lydia as a living human. Between Benigno and Alicia there is still a human relationship, a web spun of hope and disappointment, promises and failure. She can count on him, as long as she cannot live up to her own accountability.

\section{LIVING UPRIGHT AS THE TELOS OF CHRISTIAN ETHICS}

I like to show how the ideal of autonomy understood as the individual capability to live a life on one's own amidst others, receives a powerful support from the inner core of Christian ethics as the power to live upright.

The Christian ethos and the Christian narrative are closely related. ${ }^{15}$ The early Christians believed that the religious distance between God and man had been abolished in the way of the historical Jesus. Out of his love for humanity God renounces his divine status and humbles himself by becoming a human being. In Jesus the transcendent God lovingly and in a healing way approaches humanity in its transitoriness, misery, and guilt. But alongside the humiliation there is the exaltation. The actual human being Jesus, in whom God incarnates himself, partakes of the position and the power of God as the risen one.

The ethos follows the narrative in its double movement of humiliation and exaltation. Just like the love of God bridges the distance to lost humanity, in the actual behaviour of one person to

12 Amartya Sen, Development as Freedom, New York 1999, 75.

13 Idem, 63.

$14 \mathrm{Or}$, if development is no longer possible, to preserve one's unique identity as long, and as intact

as possible. Cf. Hilde Lindemann, "Holding One Another (Well, Wrongly, Clumsily) in a Time of

Dementia”. In: Metaphilosophy, Vol. 40 (2009), Nos. 3-4, 416-424.

15 For the following: cf. Gerd Theissen, Die Religion der ersten Christen, Gütersloh 2000. 
another one's own personal and social boundaries are crossed. Charity is loving one's enemy (Mt 4.43ff.), the alien (Lk 10:25ff.), the sinner (Lk 7:36ff.).

The deepening and radicalization of this tendency to cross boundaries in the ethos of Christian charity can only be understood if the second fundamental early Christian value - humility (humilitas) - is included. "... whoever wants to become great among you must be your servant, and whoever wants to be first must be slave of all. (Mk 10:43, 44 NIV; cf. 9.35, Mt 23:11)". In the ethos a switch of social position is in view which finds its divine example in the narrative. Those in high places are supposed to give up their status, those of lowly status receive authority.

A Christian revolution of values? Not that Christianity introduced new values that were unknown to pagan or Jewish morality. What is new, however, is the mix of values, in which charity is dissociated from its social connection to status and position and is tied to the virtue of humility.

A double transfer of values takes place, in which the ethos follows the narrative. In the first place there is an 'upward transfer' of the simple morality of solidarity. The foundation of Christian charity is the 'natural' popular morality of being forgiving and being a good neighbour which was and is general practice among common folk a form of being 'neighbourly': the horizontal solidarity in which one neighbour helps another along. Already in Israel this morality of the common people was extended and radicalized by including the widow, the orphan, and the alien. Now Christianity is distinctive in that this ethic 'of underneath' is not restricted to the common people but is applied to everybody, regardless of social role or station. The mighty cannot claim exception to practicing 'charity' or 'solidarity' based on their political responsibility. This is the first value transfer: from the bottom up. Ethos follows the narrative: the humble is exalted.

Conversely - and in the second place - there is also a top-down transfer. The East and classical antiquity held to a 'top-down ethics' in which the social elite was supposed to contribute to the well being of its subjects. Aristocracy should have a benefactor's mentality. On their tombstones many Egyptian officials appeal to the fact that they clothed the naked and fed the hungry. What is characteristic for the early Christian ethos is that this aristocratic ethics of beneficence (a form of vertical solidarity, of philanthropy) gets democratized. It merges with horizontal charity, the ethics of reciprocity of the common people. A top-down transfer of values takes place. Here too ethos follows the narrative. After all, Christians believe they will reign with Christ. Even if they are humiliated, in God's eyes they are an aristocracy in heaven, seated at the right and left side of the Lord in his kingdom (cf. Mt. 20: 20; Acts 2:26f.; 3:21; 20:6, symbasileia). So one should behave in a manner worthy of royalty even now, even if one is a just an ordinary person. In this way the solidarity values of the upper and lower social strata are merged in early Christianity.

This Christian ethos can be summarized in one word: mercy, or compassion. Mercy goes back to the Latin misericors, the neologism Augustine introduced to the Christian world. Misericordia: the heart that opens itself to the misery of others.

The parable of the Good Samaritan. (Lk 10:25ff.) informed and shaped the Christian ethics of misericordia (mercy/compassion) throughout the ages in practices of care. The Samaritan is the neighbour, not based on his status and his social prestige, but solely based on his personal humility, by which he spontaneously interrupts his journey and takes care of the victim that has barely survived.

Images sometimes tell more than words. I shall show how in the iconography of the Good Samaritan the dramatic dynamics of the care relationships towards autonomy is illustrated. A moving example of drama is the painting of Giordano Luca Giordano (1685). It emphasizes the first, asymmetrical moment in this relationship of care. Oil and wine have become secondary over against the distraught appearance of the Samaritan's face, looking at the naked, white body 


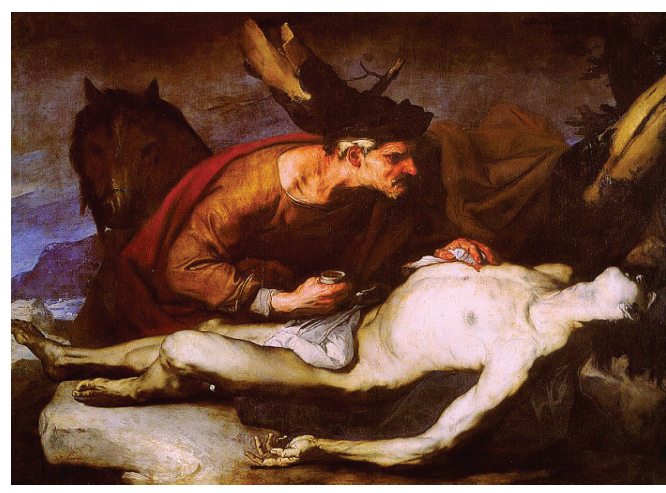

Giordano Luca Giordano
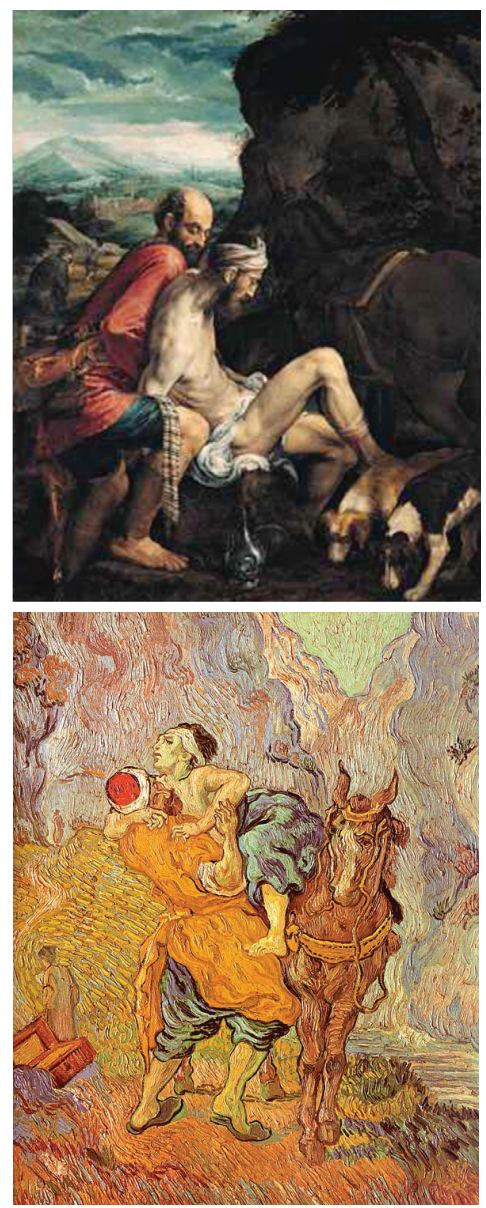
upright? of the victim that dominates the painting right in front, across its full width and in full light. Not the face - invisible, tilted all the way back - but the naked vulnerable torso is turned toward the viewer. Human dignity seems to linger only one-sidedly in the Samaritan's regard of dismay: Does a heart still beat in that chest, or is it too late for help?

The painting that the Renaissance artist Jacopo Bassano (approx. 1570) devoted to the story, doesn't focus on the asymmetrical beginnings of, but on the reciprocity in the drama of dignity. The scene depicted here, however, is about restoring the victim's autonomy. The Samaritan places himself under his body and tries to raise the victim. Apparently the bending down in compassion is not an end in itself either, not a servile self-debasement out of subservience, but is aimed at 'resurrection'. Is not the Greek word for human being, anthropos, derived from ana-trepein, to lift up something, to raise high? The human being is the creature meant to move about with 'aufrechten Gang' (Immanuel Kant), to live upright, in a status erectus. ${ }^{16}$

Cannot we define human dignity in essence as: living

The best known depiction of the good Samaritan is probably the canvas Vincent van Gogh $(1853$ - 1890) painted in the last year of his life in Saint-Rémy.

The representation is classical in the sense that here too it shows the Levite and the priest moving away. The opened and empty trunk points to the robbery that has taken place. But the representation is special, because any reference to an ethics from above, the philanthropy of the prominent, is absent here. The Samaritan is just a common man from the people, with his sleeves rolled up and wearing plain slippers on his feet. His horse is a mule, far from regally harnessed. This is more a depiction of popular neighbourliness, a horizontal care of one person for another, rather than the ethics of beneficence of the solid middle class citizen and administrator. Van Gogh is painting in a democratic century and clearly expresses his preference for and his proximity to the world of farmers and workers. Yet more can be seen than secular solidarity. Here too the Christian narrative - with which the evangelist Van Gogh was familiar as no other - strains

16 Klaas, Huizing, Der erlesene Mensch. Eine literarische Anthropologie. Freiburg 2000, 214. 
the ethos. When one person really comes to the aid of another person, not only aristocracy (the person helping from above), but also democracy (the person that helps as an equal) becomes unbalanced. Just like with Bassano the asymmetry of assistance is turned upside down. Those in high places and the humble trade places. As he tries to help him onto the horse, the traveller having pity is located underneath the victim. The former almost succumbs under the latter's heavy physical weight. The image is teeming with exertion. The emphasis is on the enormous strain that the Samaritan is under in order to lift the wounded man onto the mule. The victim clumsily holds on to him. His stocky and awkward half-naked body doesn't express beauty, or tender vulnerability like in the art of the Renaissance or Baroque, but merely dependence. The Samaritans' only aim is to lift the victim upright again.

Apparently Van Gogh sees an exalted person in the humbled one. Someone, being able and wanting to live upright. However, in his depiction of this Christian change of position he does not - like Bassano - refer to Jesus' crucifixion, but to his entry into Jerusalem (Luc. 19, 29-48). The wounded man is helped unto a mule. An allusion to Jesus' 'triumphal entry' in Jerusalem, sitting upright, like a king on his horse. Jesus, homme capable, therefore capable of suffering.

\section{CONCLUSION}

1. A care relationship is a complex whole of symmetrical and asymmetrical, formal and informal dimensions, each one with a specific ethical discourse.

2. The telos of a care relationships is restoring and guaranteeing the autonomy of the care receiver. Autonomy should be interpreted as the capability of persons to develop their uniqueness during their life course.

3. The undeniable asymmetry of the care relationship is an essential, but temporary moment in its dynamics, directed towards the restoration of autonomy.

4. This corresponds to the heart of the Christian ethos: in the Christian narrative, the asymmetry of humiliation precedes the asymmetry of the exaltation, to be understood as the restoration of human dignity as 'living upright'. The theological concept of exaltation can be interpreted as God's 'care for autonomy' in an ethic of care.

Contact details:

Prof Frits de Lange

Professor of Ethics

Prostestant Theological University

The Netherlands

Extraordinary Professor

Discipline Group of Systematic Theology and Ecclesiology

Stellenbosch University 